\title{
R \& D figures show US innovation study may be redundant
}

NEW estimates of the amount of money spent by US industry on research and development indicate that a major interagency study of industrial innovation announced by President Carter only two months ago may already be partly redundant.

The interagency study, which is being carried out by the Department of Commerce, was established largely at the instigation of Dr Frank Press, the President's science adviser. And a major source of concern brought to the administration's attention by $\mathrm{Dr}$ Press was the apparent decline in industrial investment in research and development, accompanied by a shift in emphasis from long-term to short-term goals.

However a survey of 624 companies, which between them account for 90 per cent of all privately-funded R \& D performed by US companies, published last week in Business Week showed that the companies spent a totäl of more than $\$ 18$ billion on $\mathrm{R} \& \mathrm{D}$ in 1977, an increase of 16.4 per cent over 1976.

Even after allowing for inflation, the figures indicate a net increase in private R \& D of 10 per cent. And in some industries, such as semiconductors, instruments, office equipment and "miscellaneous manufacturing", the figure was significantly higher.

Further evidence that the situation may not be as gloomy as some portray

is provided by a forecast survey made recently by McGraw Hill, which predicts that between 1977 and 1978 the porportion of $\mathrm{R} \& \mathrm{D}$ funds devoted to new products - a category of particular concern to the administration-will in-

crease from 26 to 33 per cent, while that devoted to the improvement of existing products, which had increased steadily from 48 per cent in 1975 to 59 per cent in 1977, will fall back again to 48 per cent in 1978 .

\section{France lifts objections to renegotiating US-Euratom agreement}

THE embargo placed by the US on licensing further exports of nuclear fuels and materials to Europe-including enriched uranium to research reactors in France and Germany-is likely to be lifted in the near future. This follows the French government's agreement to lift the objections to renegotiating the agreement between the US and Euratom which covers such exports.

The US had imposed the embargo from the middle of April, 30 days after President Jimmy Carter had signed the nuclear non-proliferation act. This act requires the re-negotiation of all bilateral agreements covering the export of nuclear fuels in the light of new safeguard provisions which determine whether an export licence will be granted.

The European Economic Commission in Brussels had originally drafted a letter to Washington agreeing to re-negotiate, but insisting that this agreement should not prejudice the outcome of the negotiations. The draft also insisted that any new agreement should not pre-empt the outcome of the International Nuclear Fuel Cycle Evaluation (INFCE) study being undertaken by the International Atomic Energy Agency in Paris, the results of which are expected next year.

However the council of ministers had refused to let the letter be sent, largely at the instigation of the French government, who insisted that the US had no right to break the existing agreement unilaterally.

Following discussions between President Carter, President Giscard d'Estaing of France and Chancellor Helmut Schmidt of West Germany in Washington last month, the French objection has been withdrawn. And early this week Dr Guido Brunner, EEC Commissioner for Energy and Research, was drafting a new letter which, it is hoped, will allow renegotiation to begin-and the export of nuclear fuels to be resumed.

\section{Delegation of top US science administrators visit China}

IN a move to develop scientific and technological links between the US and China, the Carter administration has sent a top level delegation of science administrators to Peking for four days of talks.

The delegation, which was due to leave Washington today (6 July), is being led by Dr Frank Press, director of the Office of Science and Technology Policy. It also includes the heads of all the major civilian research funding bodies, including the National Science Foundation, the National Institutes of Health, the National Aeronautics and Space Administration, and the Department of Energy's Office of Energy Research.

Although there has already been much unofficial contact between scientists in the two countries-Dr Press himself headed a delegation to discuss co-operation in earthquake research in 1974, and a group of Chinese nuclear and plasma physicists is currently on a four-week visit to US universities hosted by the National Academy of Sciences-this is the first time that
China has agreed to official bilateral talks since contacts were re-opened in 1971.

The Peking talks will have four basic purposes:

- to establish official contacts in science and technology;

- to explain United States science policy;

- to assess the present state of science

\section{Soviet science schools to go}

SPECIALISEd schools, concentrating on mathematics, physics, chemistry and biology, which have for some considerable time been a feature of the Soviet educational system are to be phased out. The schools were intended to provide early training for the scientific cadres needed by the "scientifictechnological revolution"; according to a recent report, however, many pupils graduating from these schools do not go into science at all but choose other occupations. The specialised schools for foreign languages (French, English, and technology in China; and

- to suggest ways of expanding exchanges.

The White House has denied that the visit is in any way a signal to the Soviet Union--increasingly isolated by scientists in protest at the treatment of dissidents - or that it is an attempt to play the Soviets and the Chinese off against each other.

German, Spanish and Oriental languages) will remain; presumably the majority of their pupils still proceed to become linguists and interpreters.

According to Moscow radio, school children will now be switched to an "abridged syllabus" in the natural sciences. However, at a recent meeting of the Academy of Pedagogical Sciences, its president, Academician, Professor V. N. Stoletov, affirmed that this change would not be reflected in the general educational standard of school-leavers. 